\title{
TOWARDS INFLATION TARGETING IN EGYPT: THE RELATIONSHIP BETWEEN EXCHANGE RATE AND INFLATION
}

\author{
Aliaa Nabil Khodeir \\ Department of Economics, Helwan University, Egypt
}

Accepted: April 2012

\begin{abstract}
Since the Egyptian economy has recently moved towards inflation targeting, it became very important to know whether exchange rate movements have serious inflationary implications or not. To investigate this subject, the study aims to analyse the relevance of inflation with the exchange rate by using the Grangercausality test. Two indicators of inflation will be used, the consumer price index (CPI) and wholesale price index (WPI). In general, the results show a strong relationship between the two variables in a way that may give support to the application of 'flexible inflation targeting regime instead of strict inflation targeting regime'.
\end{abstract}

Key words: inflation, inflation targeting, exchange rate, pass-through effect

JEL: E31

\section{1}

\section{Introduction}

Egypt has recently decided to adopt price stability as an explicit monetary policy objective. Since June 2005, the Central Bank of Egypt has taken several steps to develop its monetary policy framework with the intention to implement an inflation targeting regime in the medium term (Al-Mashat, 2008).

The transition to this regime was justified by the negative effects of exchange rate targeting and the successful experience that many emerging countries had achieved through the application of an inflation targeting regime since 1990s.Under this regime, the exchange rate fluctuations have become an important issue in economic policy debate. On one hand, a floating nominal exchange rate represents, at least from a theoretical standpoint, a requirement for a pure inflation targeting regime. Its rationale is based on the policy dilemma of the 'impossibility of the Holy Trinity' (Berganza $\&$ Broto, 2011). The idea is that even with good planning and economic management it is impossible for the central bank to achieve free capital mobility, an independent monetary policy and fixed exchange rate simultaneously. On the other hand, one of the costs of fully floating in developing economies with their greater financial and real vulnerabilities is the higher volatility of exchange rates. This can entail the problem of having a high inflationary effect of the exchange rate, known as exchange rate pass through (ERPT). Developing countries may suffer even more than developed ones due to lack of credibility of their monetary authorities. This leads to a general belief among agents that any temporary fluctuation of exchange rate behaviour is indeed permanent (Eichengreen, 2002; Edwards, 2006).

This problem constitutes a base of the fear of floating behaviour, which implies interventions in the foreign exchange market through changes in the international reserves and interest rates. The high ERPT is a point of concern for developing countries which consider adopting an inflation targeting regime. This is due to the risk of seeing the exchange rate becoming the main objective of the central bank, thus dominating the supposed primary objective of the monetary authorities, which is the inflation rate (Youssef, 2007).

In the case of Egypt, realising this problem in its developing economy, its current challenge is how to compromise between the monetary policy target that focuses on price stability and the high volatility of the exchange 
rate. In other words, it faces the dilemma of choosing between fulfilling the theoretical conditions of 'strict inflation targeting', which imply a fully flexible exchange rate or applying a "flexible inflation targeting", which entails a de facto managed floating exchange rate.

Some studies which have been performed on Egypt to show the correlation between the exchange rate and inflation depended only on the CPI as an indication of inflation. The Egyptian Cabinet study (The Egyptian Cabinet, 2004), which measures the elasticity of consumer prices to the exchange rate and uses the VAR model with daily data during the period of 2001-2004, found that there was a weak relationship between the two variables. In another study, Neaime (2008) uses quarterly data during the period of 1990-2006 for each individual country of the Middle East and North Africa (MENA) region. Using the VAR model, the results indicate that prices have responded quite swiftly to exchange rate shocks in Egypt.

Given the inconclusive results of the previous studies and their limitations as they concentrate on one indicator, the objective of this paper is to present new empirical evidence regarding the relationship between exchange rate changes and inflation, using two indicators of it: CPI, WPI.

The rest of the paper is organised as follows: section 2 briefly reviews the theoretical and empirical studies that show how the inflation and exchange rate affect each other. Section 3 presents an overview of the development of inflation indicators and exchange rate movements in the Egyptian economy during the period of the research. Section 4 presents the research methodology of the Granger-causality test applied to Egypt. A summary of the results and the policy implications are provided in section 5 .

2

\section{Literature review}

Economic theory suggests that inflation and exchange rate changes can affect each other.

From one side, inflation is a determinant of the exchange rate according to purchasing power parity (PPP) theory. It states that the exchange rate between currencies is in equilibrium when the domestic purchasing power is the same in each of the two countries. Therefore, the nominal exchange rate represents an offsetting factor to changes in relative prices. Using this definition, a high inflation in one country should be accompanied by depreciation of its exchange rate in order to return to PPP (Mungule, 2004).

There are two versions to express the PPP equation. In absolute PPP, the nominal exchange rate is equal to the ratio of the domestic price level to the foreign price level and, therefore, the real exchange rate is equal to one. In relative PPP, the rate of change in the nominal exchange rate is equal to the domestic inflation minus the foreign inflation rate so the real exchange rate remains constant.

The basis for PPP is the 'law of one price'. In the absence of transportation and other transaction costs, competitive markets will equalise the price of an identical good in two countries when the prices are expressed in the same currency. There are three caveats with this law: (1) Transportation costs, barriers to trade, and other transaction costs can be significant. (2) There must be competitive markets for the goods and services in both countries. (3) It only applies to tradable goods. Empirical evidence has shown that in the short run PPP does not hold (Ahmad \& Ali, 1999). But studies on the long-run behaviour of exchange rates have found that it can take four to ten years to equalise the purchasing power of currencies and that PPP therefore describes the long-run behaviour of exchange rates (Antweiler, 2011).

On the other side, exchange rate change is one of the external factors that determine inflation in open markets. The inflationary effect of the exchange rate can be explained by two kinds of channels. The direct channel, which is connected to the aggregate demand refers to the effect of exchange rate change on the import prices of final consumption goods that the domestic consumers pay. The indirect channel, which is related to aggregate supply refers to the effect of exchange rate change on the import prices of capital and intermediate goods, which in turn influence the cost of production that the producers pay.

There are different factors that determine 
the ERPT. At the microeconomic level, it is determined mainly by market structure, industry's share of imports, degree of product differentiation and elasticity of marginal cost (Dornbusch, 1987; Yang, 1997). At the macroeconomic level, it is determined by import prices, output growth, inflation persistence and credibility of the monetary authority (Campa \& Goldberg, 2005; Karim, 2005).

Since the 1990s the degree of EPRT has declined significantly in economies that applied an inflation targeting regime due to credibility gains (Nogueira, 2007; Kara \& Ogunc, 2008). As a result, it can be assumed that lower inflation decreases ERPT and this in turn helps in keeping inflation low (Taylor, 2000).

The mutual interaction between inflation rate and exchange rate as shown above was tested by some studies and the results seem mixed. Ndungu (1997) agrees with this mutual interaction using the Granger-non causality test based on Kenyan data during the period of 1970-1993. Nogueira (2007) shows that there was no evidence of endogeneity in a sample of some emerging and developed economics using the Granger-causality test during the period of 1983-2005. Using the same test based on annual data from Asia, the EU and North America during the period of 1991-2005, Achsani et al. (2010) found that there was a significant one-way causal relationship from the exchange rate to the rate of inflation for Asia, while the causal seemed to be in the opposite direction for non-Asian regions.

\section{3}

\section{Developments of exchange rate and inflation in the Egyptian economy}

There were significant milestones in the path of the exchange rate and inflation in Egypt during the period of the study (1990-2008). In order to spot these developments and their causes, this part will be divided into four episodes.

\subsection{From January 1990 to December 1999}

At the beginning of the 1990s, Egypt adopted a pegged exchange rate regime, where the authorities set the official exchange rate regardless of the market forces. In February 1991, the country applied a dual exchange rate containing a primary market and a free market and few months later these markets were unified into one market. The exchange rate was stabilised through this period and it ranged between Egyptian pound (EP) 3.33 per US dollar in 1991 to EP 3.39 per US dollar in 1999, which meant that the rate of change didn't exceed 1.8 per cent during all these years (National Bank of Egypt, 2002).

As a result of this stabilisation and in addition to the contractionary demand policies that followed in the first stage of the Economic Reform and Structural Adjustment Program (ERSAP), the inflation rates had a declining path. The CPI inflation was between 20 per cent in 1991 and 3 per cent in 1999 and the WPI inflation decreased from 18 per cent to 1 per cent within the same period according to IMF international financial statistics (IFS).

\subsection{From January 2000 to December 2001}

The exchange rate had faced persistent pressures in the late 1999 mainly due to the reduction of foreign reserves as a result of substantial balance of payments deficits and the increase of informal demand for the US dollar for speculation (The Egyptian Cabinet, 2003). These pressures caused series of gradual devaluations of Egyptian pound until it recorded 3.69 per US dollar in June 2000. In January 2001, the exchange rate was set to crawl within a band of \pm 1 per cent around the central rate which was set at 3.85 per US dollar. In August 2001, the band was widened to \pm 3 per cent. Nevertheless, the Egyptian pound devaluation problem exacerbated further, given that the supply of foreign exchange in the official market dropped sharply as exporters and holders of foreign currency sought more attractive rates in the black market to satisfy the excess demand. This caused the activity in the black market to expand significantly to the extent of trading at a 15 per cent premium over the official rate in 2002. During this period, the domestic currency lost about 29 per cent of its value (AlMashat \& Billmeier, 2007).

Meanwhile, the CPI inflation and WPI inflation rates were relatively low, ranging 
around 2.5 per cent and 1.4 per cent respectively. This reduction was due to the persistence of the pegged exchange rate regime that slowed the degree of ERPT, in addition to the prevailing low international commodity prices at the time (Central Bank of Egypt, 2009/2010).

\subsection{From January 2002 to December 2004}

After the formal devaluations of the domestic currency in 2001 and 2002, the Egyptian government announced in January 2003 the adoption of a floating exchange rate regime. It was introduced mainly because of the deteriorating situation in the foreign exchange market. However, the lack of credibility in this new system and public expectations of a further drastic devaluation led to a severe shortage of foreign exchange. As a result, the Egyptian pound depreciated and lost 50 per cent of its value (Youssef, 2007).

The inflation rates have increased significantly due to high ERPT of Egyptian pound depreciation. The WPI was able to show the primary effects of exchange rate shock on the economy more strongly than CPI in 2002 and 2003 (Fares \& Ibrahim, 2008). Depending on IFS data for year 2004, the CPI inflation reached to 11 per cent while the WPI recorded
17 per cent when the exchange rate of the Egyptian pound was 6.40 to the US dollar.

\subsection{From January 2005 to April 2008}

This period was characterisedby a stable exchange rate due to the establishment of the interbank foreign currency market in December 2004, and therefore the Egyptian pound strengthened. In March 2005, it appreciated for the first time since the starting of the ERSAP to reach 5.79 to the US dollar, and then it continued to improve until it recorded 5.37 to the US dollar in April 2008 according to IFS data.

This improvement was reflected in a decrease in the inflation trend through 2005 until May 2006. The trend was reversed by the effects of a set of internal factors (oil subsidy cuts and accelerating economic growth) and external factors (the rise in international food prices). During FY 2007/2008, the CPI inflation reached double-digit levels around 20 per cent (Central Bank of Egypt, 2009/ 2010).

Figures (1) and (2) trace respectively the exchange rate movements with the CPI and WPI inflation rates of Egypt during the period of study. In general, they showed a close link between the exchange rate and inflation, especially for wholesale prices.

Figure 1

CPI inflation and exchange rate fluctuations, 1990-2008 (12- month percentage change)

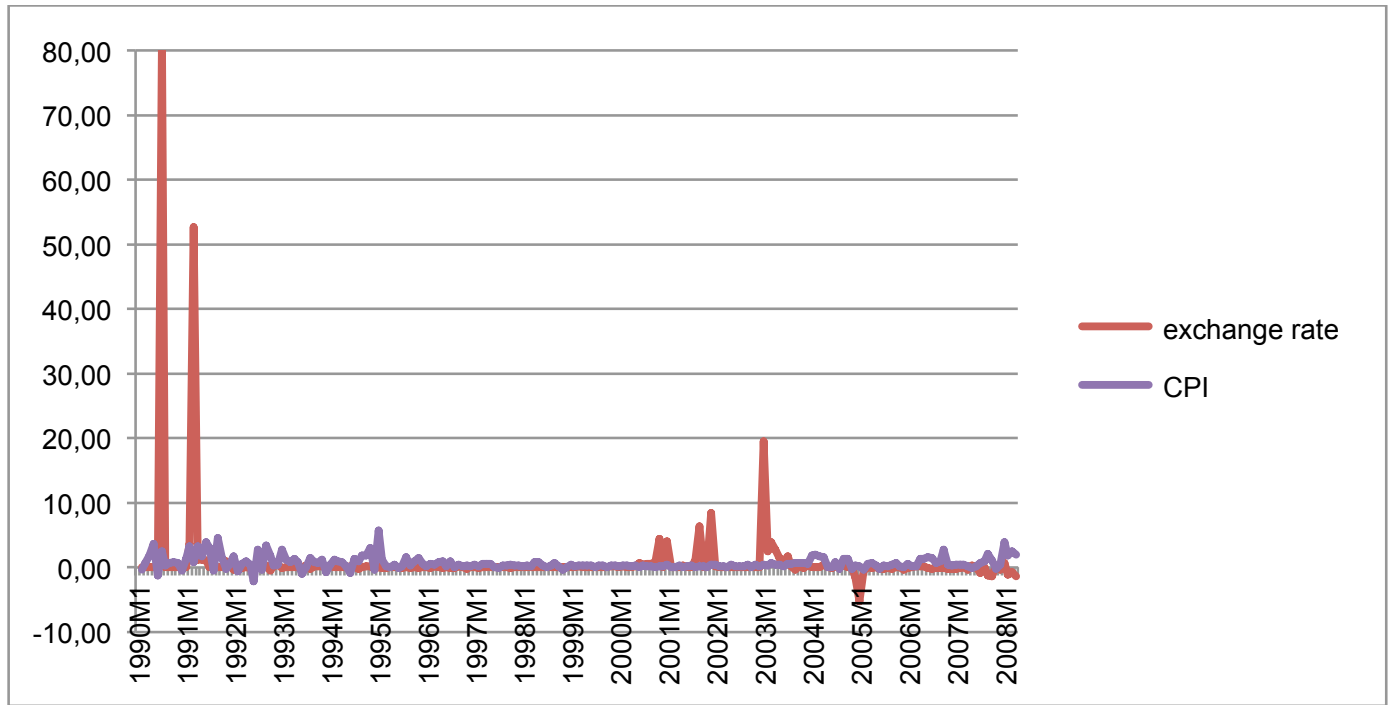

Source: Author's calculations 
Figure 2

WPI inflation and exchange rate fluctuations, 1990-2008 (12- month percentage change)

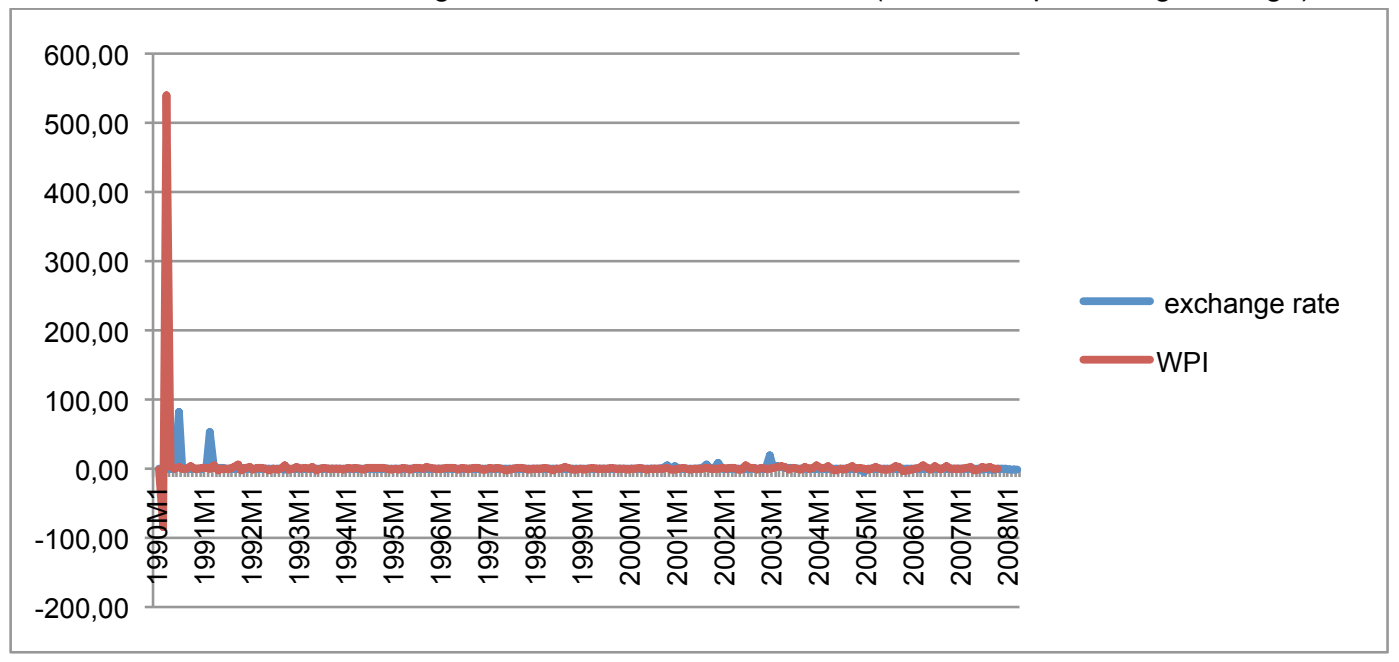

Source: Author's calculations

4

\section{Applied model}

In this section, the Granger-causality test is applied to explore the nature of relationship between the exchange rate change and inflation. Data for Egypt was collected from the IMF international financial statistics database. The period of estimation corresponded to the interval from $1990 \mathrm{M}_{1}$ to $2008 \mathrm{M}_{4}$. To express inflation, this paper used both CPI and WPI. Exchange rate data is the change of the Egyptian pound per unit of US dollar (end of month). A positive variation means depreciation of the domestic currency, and a negative one means appreciation. Before running the causality, the data set becomes significantly stationary using Ducky-Fuller test.

The Granger causality test involves estimating the following regression model:

$$
\begin{aligned}
& \Delta \mathrm{P}_{\mathrm{t}}=\sum_{\mathrm{i}=1}^{\mathrm{n}} \alpha_{\mathrm{i}} \Delta \mathrm{E}_{\mathrm{t}-\mathrm{i}}+\sum_{\mathrm{i}=1}^{\mathrm{n}} \mathrm{B}_{\mathrm{i}} \Delta \mathrm{P}_{\mathrm{t}-\mathrm{i}}+\mathrm{U}_{\mathrm{t}} . \\
& \Delta \mathrm{E}_{\mathrm{t}}=\sum_{\mathrm{i}=1}^{\mathrm{n}} \theta_{\mathrm{i}} \Delta \mathrm{E}_{\mathrm{t}-\mathrm{i}}+\sum_{\mathrm{i}=1}^{\mathrm{n}} \delta_{\mathrm{i}} \Delta \mathrm{P}_{\mathrm{t}-\mathrm{i}}+\mathrm{V}_{\mathrm{t}} .
\end{aligned}
$$

where:

$\Delta \mathrm{P}$ is the inflation rate measured as the rate of change in each of the price indices (first as $\Delta \mathrm{CPI}$, second as $\Delta \mathrm{WPI}$ ).

$\Delta \mathrm{E}$ is the nominal exchange rate change.

$\mathrm{U}_{\mathrm{t}}$ and $\mathrm{V}_{\mathrm{t}}$ are disturbances.

Equation (1) postulates that the inflation rate is related to lagged values of itself as well as of exchange rate change. Equation (2) postulates that exchange rate change is connected to past values of itself in addition to the inflation rate.

The results of the Granger-causality test between exchange rate and the two indices of inflation are shown in tables (1) and (2).

\section{Table 1}

Results of Granger-causality test between exchange rate and CPI inflation

\begin{tabular}{|l|c|c|c|}
\hline \multicolumn{1}{|c|}{ Direction of causality } & Lags No. & F-statistic & P-value \\
\hline$\Delta \mathrm{E}$ doesn't Granger cause $\Delta \mathrm{CPI}$ & 2 & 0.5386 & 0.5843 \\
\hline$\Delta \mathrm{CPI}$ doesn't Granger cause $\Delta \mathrm{E}$ & 2 & 4.5237 & 0.0119 \\
\hline$\Delta \mathrm{E}$ doesn't Granger cause $\Delta \mathrm{CPI}$ & 6 & 2.3017 & 0.0359 \\
\hline$\Delta \mathrm{CPI}$ doesn't Granger cause $\Delta \mathrm{E}$ & 6 & 1.7479 & 0.1116 \\
\hline$\Delta \mathrm{E}$ doesn't Granger cause $\Delta \mathrm{CPI}$ & 8 & 3.4971 & 0.0008 \\
\hline$\Delta \mathrm{CPI}$ doesn't Granger cause $\Delta \mathrm{E}$ & 8 & 2.2417 & 0.026 \\
\hline
\end{tabular}


Table 2

Results of Granger-causality test between exchange rate and WPI inflation

\begin{tabular}{|l|c|c|c|}
\hline \multicolumn{1}{|c|}{ Direction of causality } & Lags No. & F-statistic & P-value \\
\hline$\Delta$ E doesn't Granger cause $\Delta$ WPI & 2 & 2.5178 & 0.0831 \\
\hline$\Delta$ WPI doesn't Granger cause $\Delta \mathrm{E}$ & 2 & 1.2087 & 0.3007 \\
\hline$\Delta$ E doesn't Granger cause $\Delta$ WPI & 6 & 1.81097 & 0.09 \\
\hline$\Delta$ WPI doesn't Granger cause $\Delta \mathrm{E}$ & 6 & 1.0886 & 0.3707 \\
\hline$\Delta \mathrm{E}$ doesn't Granger cause $\Delta \mathrm{WPI}$ & 8 & 2.897 & 0.0046 \\
\hline$\Delta$ WPI doesn't Granger cause $\Delta \mathrm{E}$ & 8 & 0.8056 & 0.5983 \\
\hline
\end{tabular}

Source: Author's calculation

Depending on the rate of change of CPI as a measure of inflation, table (1) points to a unidirectional causality running from the price growth to the exchange rate change when considering two lagged periods and 1 per cent of significance. The unidirectional causality moves in the opposite way from exchange rate change to price growth with six lagged periods and 5 per cent of significance. This reflects the appearance of ERPT effect. Meanwhile, there is a bi-directional causality between the two variables at 8 lagged periods and 5 per cent of significance. It means that the nominal exchange rate depreciation will increase inflation and the inflation will result in exchange rate depreciation.

The quick response of exchange rate changes to price growth shows that inflation plays an important role in exchange rate fluctuations on the short run. This matches the open economy of Egypt, while the relatively slower exchange rate ERPT effect could be attributed to some distortions resulting from the interference of the Egyptian government with price control and subsidies. Consequently the interference may be an obstacle in the variability of consumer prices. This explanation agrees with Al-Mashat \& Billmeier (2007) who showed a sizeable share of administered prices in CPI, around one third of the items.

To examine the relation between exchange rate and inflation at another stage of commodity distribution, table (2) runs the regression between exchange rate change and WPI change. It shows that the causality moves from exchange rate change to price growth. This direction of causality does not change under different lag periods. Also, it can be seen that WPI reflects the impact of exchange rate change on inflation more rapidly than the CPI.
While the impact needs only 2 lagged periods to start with regard to WPI, it takes 6 lagged periods with regard to CPI. This may reflect the different composition of the two indices. WPI is driven mainly by prices of tradable goods, whereas CPI has large distribution between tradable and non-tradable goods (Bailliu \& Fuiji, 2004). This means the larger the share of tradable goods in a certain price index, the more likely the effect of exchange rate on price level.

There is indeed an inflationary mechanism running from exchange rate change in both tables, thus reinforcing the existence of the ERPT phenomenon. This may be caused by the low price elasticity of import demand and high propensity to import in Egypt as a developing country. According to its import structure, there is a significant dependence on intermediate and capital goods in order to satisfy the requirements of economic development. In year 2008, the intermediate goods accounted for 66 per cent of total import, while the capital goods accounted for 15 per cent (Ministry of Foreign Trade and Industry, 2010). This means any exchange rate depreciation will be reflected in higher import costs without the ability to decrease import demand significantly. Therefore, the domestic price level will increase specially in the presence of a pricewage spiral.

The results of this study proved the presence of the ERPT phenomenon in the Egyptian economy. By adopting the inflation targeting regime, ERPT will be tamed. The monetary authority will gain credibility from its role in targeting this regime. Therefore after a period of low inflation, the effect of the exchange rate on the formation process of agents' expectations is likely to fade. 
5

\section{Concluding remarks}

The analysis in this paper was based on the Granger-causality test for monthly data during the period of 1990-2008. It showed a strong relationship between exchange rate changes and inflation. Both indicators of inflation succeeded in reflecting a clear ERPT phenomenon, but WPI showed a faster response to exchange rate changes than CPI. This is due to the distortions of CPI as many basic goods in Egypt have been subjected to price control and explicit or implicit subsidies (e.g. basic food stuffs, energy). This in turn ensures the insufficiency of CPI in reflecting the inflationary effect of the exchange rate.

The result that the exchange rate is a significant determinant of inflation has an interesting implication for Egypt's economic ability to attain an effective inflation targeting regime. It gives a clear justification for applying this regime to limit the ERPT phenomenon but there will be some challenges for consideration. First, the rise in the inflation rate is mainly due to the effect of the Egyptian pound's depreciation. With uncertainty about future price trends in the transient period of applying the regime, the monetary authorities not only have to deal with high levels of inflation, but also with a surge in inflation expectations. Second, the monetary authority may need to intervene more frequently in the foreign exchange market to decrease its fluctuations. Third, with regard to the clarity of ERPT effect and its consequences, there is the risk that the exchange rate becomes the main focus of the central bank, thus confusing the public about the priorities of the central bank, which distorts expectations.

Accordingly, to face the dilemma between applying a 'strict inflation targeting', or applying 'flexible inflation targeting', the central bank may choose to smooth short-run exchange rate movements to attain its target inflation rate. This does not mean that the central bank does not allow the currency to adjust to a new longrun equilibrium following a shock, but that it will not let this movement interfere with its attainment of the inflation targets. This implies that possible transparent interventions in the foreign exchange market are required for the attainment of the inflation target. This may justify applying 'flexible inflation targeting' by policymakers. In this context, a recent study has shown that although the inflation targeting regime has led to higher exchange rate instability than alternative regimes, foreign exchange interventions in some inflation targeting countries have been more effective to lower volatility than in non-inflation targeting countries (Berganza \& Broto, 2011).

The main policy recommendations may also include: 1. To limit the over-vulnerability of the economy to exchange rate fluctuations by increasing the openness of the economy and improving the exporting ability. 2. To activate sufficiently developed channels beside exchange rate to guide monetary policy choices.

\section{References}

ACHSANI, N., FAUZI, A. \& ABDULLAH, P. 2010. The relationship between inflation and real exchange rate: comparative study between Asean +3 , the EU and North America. European Journal of Economics, Finance and Administrative Sciences, 18.

AL-MASHAT, R. \& BILLMEIER, A. 2007. The monetary transmission mechanisms in Egypt. Paper presented in the $14^{\text {th }}$ Annual Conference of Economic Research Forum.

AHMAD, E. \& ALI, S. 1999. Exchange rate and inflation dynamics, Pakistan. Development Review, 38.

AL-MASHAT, R. 2008. Monetary policy in Egypt: a retrospective and preparedness for inflation targeting. The Egyptian Center for Economic Studies, Working Paper 136.

ANTWEILER, W. 2011. Purchasing power parity. University of British Columbia. Available at: http://fx.sauder.ubc.ca/PPP.html [accessed 2011-30-11].

BAILLIU, J. \& FUJII, E. 2004. Exchange Rate pass-through and the inflation environment in industrialized countries: an empirical investigation, Bank of Canada Working Papers, 04-21. 
BERGANZA, J. \& BROTO, C. 2011. Flexible inflation targets, forex intervention and exchange rate volatility in emerging countries. Banco de Espana Working Paper, 1105.

CAMPA, J. \& GOLDBERG, L. 2005. Exchange rate pass-through into import prices, The Review of Economics and Statistics, 87(4).

CENTRAL BANK OF EGYPT. (2009/2010). Demand for broad money in Egypt: stability testing and monetary policy implications. Economic Review, 50(3).

DORNBUSCH, R. 1987. Exchange rates and prices. American Economic Review, 77(1).

EDWARDS, S. 2006. The relationship between exchange rates and inflation targeting revisited. NBER Working Paper, 12163.

EICHENGREEN, B. 2002. Can emerging markets float? Should they inflation target? Central Bank of Brazil Working Paper, 36.

FARES, H. \& IBRAHIM, A. 2008. Wage-price causality in the Egyptian economy (1990-2005). The Egyptian Center for Economic Studies Working Paper, 136.

KARA, H. \& OGUNC, F. 2008. Inflation targeting and exchange rate pass-through: the Turkish experience. Emerging Markets Finance and Trade, 44(6).

KARIM, B. 2005. Exchange rate pass-through into import prices in developing countries: an empirical investigation. Economic Bulletin, 3(26).

MINISTRY OF FOREIGN TRADE AND INDUSTRY. 2010. Monthly foreign trade statistics report. International Trade Point, March.

MUNGULE, K. 2004. The determinants of the real exchange rate in Zambia. African Economic Research Consortium Research Paper, 146.

NATIONAL BANK OF EGYPT. 2002. Development of exchange rate in Egypt. Economic Bulletin, 55(1). NEAIME, S. 2008. Monetary policy transmission and targeting mechanisms in the Mena region. Economic Research Forum Working Paper Series, 395.

NOGUEIRA, R. 2007. Inflation targeting and exchange rate pass-through. Econ. Aplic., 11(2).

NDUNGU, N. 1997. Price and exchange rate dynamics in Kenya: an empirical investigation (1970-1993). AERC Research Paper, 58.

TAYLOR, J. 2000. Low inflation, pass-through and the pricing power of firms. European Economic Review, 44(7).

THE EGYPTIAN CABINET. 2003. Early warning system for crises of currency markets. The information and decision support center.

THE EGYPTIAN CABINET. 2004. The effect of exchange rate change on inflation rate in Egypt: passthrough effect, The information and decision support center.

YANG, J. 1997. Exchange rate pass-through in us manufacturing industries. Review of Economics and Statistics, 79(1).

YOUSSEF, H. 2007. Towards inflation targeting in Egypt: fiscal and institutional reforms to support disinflation efforts. European Commission Economic Papers, 288. 